OPEN ACCESS

Edited by:

Jan Polák,

Charles University in Prague, Czechia

Reviewed by:

Nirav Dhanesha,

University of lowa, United States

Zhichao Feng,

Albert Einstein College of Medicine,

United States

*Correspondence:

Allah Bukhsh

allah.bukhsh@monash.edu

Specialty section: This article was submitted

to Diabetes,

a section of the journal

Frontiers in Public Health

Received: 20 April 2017

Accepted: 06 June 2017

Published: 27 June 2017

Citation:

Bukhsh A, Lee SWH, Pusparajah P, Khan AH and Khan TM (2017) Psychometric Properties of the Urdu

Version of Diabetes Knowledge

Questionnaire.

Front. Public Health 5:139.

doi: 10.3389/fpubh.2017.00139

\section{Psychometric Properties of the Urdu Version of Diabetes Knowledge Questionnaire}

\author{
Allah Bukhsh ${ }^{1 *}$, Shaun Wen Huey Lee ${ }^{1}$, Priyia Pusparajah², Amer Hayat Khan ${ }^{3}$ \\ and Tahir Mehmood Khan ${ }^{1}$ \\ 'School of Pharmacy, Monash University, Bandar Sunway, Malaysia, ' Jeffrey Cheah School of Medicine and Health \\ Sciences, Monash University, Bandar Sunway, Malaysia, ${ }^{3}$ School of Pharmaceutical Sciences, Universiti Sains Malaysia, \\ Gelugor, Penang, Malaysia
}

Objective: Patient education is a key element in the treatment of diabetes. Assessment of diabetes knowledge is important for optimum treatment. For the assessment of diabetes knowledge, validated tool is essential. None of such validated tool is available in Urdu language. Therefore, the aim of this study was to translate and examine the psychometric properties of the 24-item Urdu version of Diabetes Knowledge Questionnaire (DKQ) among type 2 diabetes patients.

Methods: Standard "forward-backward" process was used to translate DKQ into Urdu language. Later, it was validated on a convenience sample of 130 patients with type 2 diabetes, between July and September 2016. Internal consistency was assessed by reliability analysis, one-way analysis of variance was applied for known group validity and multivariate linear logistic regression was applied for identifying significant predictors for patients' DKQ score.

Results: Good internal consistency was observed for DKQ (Cronbach's $\alpha=0.702$ ). The mean $\mathrm{HbA} 1 \mathrm{c}$ of the patients was $8.55 \%( \pm 1.91)$. DKQ scores of patients' with "good glycemic control" (14.22 \pm 2.4$)$ were observed significantly higher $(P<0.05)$ than patients with "poor glycemic control" (12.56 \pm 2.75$)$. Multiple linear regression revealed that patients' $\mathrm{HbA} 1 \mathrm{c}(\mathrm{OR}-0.17, \mathrm{Cl}-1.111,-0.023)$ and patients' education (OR 0.17 , $\mathrm{Cl}-0.032,0.758$ ) were significant predictors for DKQ sum score.

Conclusion: Urdu version of the DKQ is a valid and reliable instrument for adequate estimation of disease knowledge and its association with glycemic control in type 2 diabetes patients in Pakistan.

\section{Keywords: diabetes, patient knowledge, psychometric analysis, HbA1c, Pakistan}

\section{INTRODUCTION}

Diabetes, one of the most common non-communicable disease worldwide (1). According to International Diabetes Federation, approximately 415 million people living with diabetes mellitus (DM) worldwide, which is expected to reach 642 million by 2040 (2). Pakistan has been ranked 7th in diabetes disease burden in the world with prevalence rate of $7.6-11 \%$ in 2011 , it is projected to 
reach $15 \%$ (14 million) by 2030 . If the present scenario continues, Pakistan is expected to move to top 4th place (3).

Type 2 diabetes mellitus (T2DM) is a metabolic disorder and its optimum management requires not only medication use but an adequate patient disease knowledge and self-care behaviors. Poor diabetes control lead toward increased risk of micro- and macro-vascular complications, e.g., diabetic nephropathy, diabetic neuropathy, coronary arty disease, and diabetic foot (4). Diabetes is a lifelong disorder and comorbidities associated with its poor control impose an enormous economic burden on individual, society, and health-care system $(5,6)$. However, effective glycemic control may impede the chances of such diabetes associated morbidities and mortalities (7).

Glycemic control is one of the major goals of diabetes management. Glycemic control can be evaluated with the help of glycated hemoglobin (HbA1c), which represents average blood glucose levels of previous $2-3$ months period. For this reason, $\mathrm{HbA1c}$ is known to be the best indicator for long-term glycemic control in people with DM (7). In order to achieve good glycemic control, it is necessary to measure glycated hemoglobin (HbAlc) and assess patient's diabetes knowledge.

Although diabetes disease knowledge alone does not ensure the desired modifications for effective self-care, yet diabetes knowledge is an important first step to measure the outcome and optimization of the patient education programs (8-10). Nevertheless, easy to administer, reliable, and valid tools to patients' diabetes knowledge are scarce (9). It is the need of time to run effective diabetes educational awareness programs for people to educate them about their life style interventions $(11,12)$. This will greatly help to decrease diabetes prevalence.

To assess the patients' diabetes knowledge, Diabetes Knowledge Questionnaire (DKQ) has been developed by the Starr County Diabetes Education Study (10). DKQ was developed in English language and has been translated and validated in many languages, but it has not been translated and validated in Pakistan. Therefore, study aim was to translate and validate DKQ among T2DM patients in Urdu language in Pakistan, as Urdu is the national language of Pakistan and is widely spoken by its population. Additionally, the degree of association of diabetes knowledge will be investigated with glycemic control (HbA1c) in the present study.

\section{MATERIALS AND METHODS}

\section{Study Design}

Cross-sectional study design was adopted for data collection. A target convenience sample of 160 patients with type $2 \mathrm{DM}$ was estimated. This validation study was performed from July to September 2016 at Akhuwat Hospital Lahore, Pakistan, and Awan Medical Complex Lahore, Pakistan.

\section{Instrument Translation}

From the many available published questionnaires, we selected the Diabetes Knowledge Questionnaire 24, developed for the Starr County Diabetes Education Study. This tool originally developed with 60 items was later abridged to 24 items. Permission of the original authors was obtained for translation and usage of DKQ. The questionnaire was translated into Urdu using a standardized forward and backward translation procedure, as recommended by Bradley (13), briefly, the translation process involved two native linguistic experts who translated word to word from the original English DKQ version to Urdu version (forward translation). For rechecking the adequacy of the translation, the translated questionnaire was submitted to the linguistic department, who proposed some minor grammatical corrections. Upon correcting these errors, forward translation phase of the tool was completed. Later on, two linguistic experts translated back the corrected Urdu version to English version (backward translation), the resulting discrepancies were resolved resulting in the finalized Urdu version for face validity testing. The translated DKQ Urdu version was administered to 20 Urdu speaking diabetes patients, attending outpatient department of the hospital for face validity followed by appropriate modifications. These patients' data were not included in final data analysis.

\section{Scoring Criteria}

The scoring of the DKQ involves summing up the scores of all the correct items of each participant, where higher score indicated better patient's diabetes knowledge. One point was given to each correct answer and no point for the incorrect option.

\section{Study Participants and Setting}

Inclusion criteria for the study were adult ( $>30$ years) patient of type $2 \mathrm{DM}$, diagnosed at least 1 year before, with recent $\mathrm{HbA1c}$ lab test (not more than 8 weeks old form the date of interview), taking hypoglycemic medications and sufficient communication skills in the Urdu language. Patients with terminal illness or cognitive impairments and who could not complete the interviews were excluded. Study participants were interviewed face-to-face for collection of sociodemographic data and were assessed by using the translated (Urdu) version of DKQ. 130 eligible patients showed their willingness for participation in the study (response rate approximately $81.3 \%$ ). Patient's medical records were reviewed by the investigator on the same day for HbA1c levels, nature and number of hypoglycemic agents, and for the presence of comorbid conditions.

\section{Ethics Approval}

This study was approved and carried out with the recommendations of the Monash University Human Research and Ethics Committee, Akuwat diabetic clinic Lahore, and Awan Medical Complex Lahore. Written consent was provided by all subjects before participation in the study, in accordance the Declaration of Helsinki.

\section{Statistical Analysis}

The analyses were performed using SPSS 21.0.0 (SPSS Inc., Chicago, IL, USA). Normality of distribution of data was first determined by Kolmogorov-Smirnov test. Frequencies and descriptive statistics were used for demographics presentation, while means and SDs were calculated for the continuous variables. Scale items characteristics were evaluated by corrected item total correlations, corrected item sub-scale correlations, 
an increase of the scale's reliability coefficient (Cronbach's $\alpha$ ) in case of item deletion and the items' correlations with the HbA1c value. Cronbach's $\alpha$ values were appraised by the following criteria: $>0.9=$ Excellent, $>0.8=$ Good, $>0.70=$ Acceptable, $>0.6=$ Questionable, $>0.5=$ Poor and $<0.5=$ Unacceptable (14).

One-way analysis of variance was conducted for known group's validity, to compare the effect on patients' DKQ scores, by $\mathrm{HbA1c}$, after categorizing the respondents in to three groups on the basis of their HbA1c values. Patients with $\mathrm{HbA1c}$ values up to $7.5 \%$ were classified as "good glycemic control," patients with values between 7.6 and $8.9 \%$ classified as "medium glycemic control," and patients with values from $9.0 \%$ as "poor glycemic control."

Multiple linear regression was calculated to predict patients' DKQ sum score based on type of hypoglycemic agent, education, $\mathrm{Hb} 1 \mathrm{Ac}$, gender, BMI, age categories, and diabetes disease duration of the study participants. $P$-value of $<0.05$ (two-tailed test) was considered as criterion of statistical significance.

\section{RESULTS}

The study included 160 patients with type 2 diabetes in which 30 patients were excluded after data collection due to lack of either HbA1c results $(n=18)$ or insufficient information about their disease $(n=12)$. The mean age of the patients was 51.34 years $(\mathrm{SD}=10.40)$, mean BMI was $29.68( \pm 6.16) \mathrm{kg} / \mathrm{m}^{2}$, with a slight preponderance of female gender (57.6\%). Seventy-two (55.4\%) were in age ranging 45-60 years and $25(19.2 \%)$ were above 60 years of age. The majority of patients $(38.5 \%)$ had no formal education, followed by university level $(26.2 \%)$ and secondary level $(25.4 \%)$ education. The mean duration of diabetes was 8.46 years $(\mathrm{SD}=7.03)$. Majority of patients were on combination oral anti-diabetes medicines (42.3\%) and did not use insulin for their diabetes management, followed by combination of oral hypoglycemic agents (OHA) and insulin (39.2\%). Majority of the patients were using $\mathrm{OHA}$ alone $(45 \%)$ or in combination with insulin (44\%), whereas only $11 \%$ were using insulin exclusively. The mean duration of diabetes illness and HbAlc were 8.46 $( \pm 7.03)$ years and $8.55 \%( \pm 1.91)$. Approximately $62 \%$ of the patients had $\mathrm{HbAlc}$ values above $7.5 \%$ (59.5 $\mathrm{mmol} / \mathrm{mol})$. The demographic characteristics of the patients are presented in Table 1, including the frequency distribution of the study patients and disease-related data.

\section{Internal Consistency}

The items in this tool were found to be highly consistent internally. The Cronbach's $\alpha$ for testing the internal consistency was 0.702 and in no case an item deletion led to a significant $(P<0.05)$ increase of the scale's $\alpha$ coefficient (see Table 2$)$. Two items (No. 3 and No. 15) have significant negative correlation with $\mathrm{HbA} 1 \mathrm{c}$, whereas item No. 17 and No. 20 sowed significantly $(P<0.05)$ positive correlation with HbA1c. Three items (No. 14, No. 18, and No. 23) showed highly significant $(P<0.01)$ positive correlation with $\mathrm{HbA1c}$. A detailed overview of the above item characteristics is displayed in Table 2.
TABLE 1 | Demographic and disease characteristics of the study patients with differences in $\mathrm{DKQ}$ and $\mathrm{HbA} 1 \mathrm{c}(N=130)$.

\begin{tabular}{|c|c|c|c|c|c|}
\hline Variables & $\begin{array}{c}\text { Frequency } \\
\text { (\%) }\end{array}$ & $\begin{array}{c}\text { DKQ } \\
\text { Mean (SD) }\end{array}$ & $P$ & $\begin{array}{c}\text { HbA1c } \\
\text { Mean (SD) }\end{array}$ & $P$ \\
\hline Age & & & $0.52^{\mathrm{a}}$ & & $0.70^{\mathrm{a}}$ \\
\hline$<45$ years & 33 (25.4) & $13.73( \pm 2.43)$ & & $8.46( \pm 1.85)$ & \\
\hline $45-60$ years & $72(55.4)$ & $13.08( \pm 2.95)$ & & $8.67( \pm 1.98)$ & \\
\hline$>60$ years & 25 (19.2) & $13.20( \pm 2.34)$ & & $8.32( \pm 1.84)$ & \\
\hline \multicolumn{6}{|l|}{ Gender } \\
\hline Male & 55 (42.3) & $13.15( \pm 2.43)$ & $0.11^{b}$ & $8.79( \pm 2.10)$ & $0.18^{b}$ \\
\hline Female & $75(57.7)$ & $13.36( \pm 2.91)$ & & $8.38( \pm 1.76)$ & \\
\hline Education & & & $0.04^{a, *}$ & & $0.09^{a}$ \\
\hline No formal & $50(38.5)$ & $13.23( \pm 3.27)$ & & $9.07( \pm 1.99)$ & \\
\hline Primary & $13(10)$ & $13( \pm 2.38)$ & & $8.39( \pm 1.59)$ & \\
\hline Secondary & $33(25.4)$ & $13.18( \pm 2.13)$ & & $8.31( \pm 1.93)$ & \\
\hline University & 34 (26.2) & $14.32( \pm 2.14)$ & & $8.08( \pm 1.77)$ & \\
\hline $\begin{array}{l}\text { Diabetes } \\
\text { duration }\end{array}$ & & & $0.35^{a}$ & & $0.30^{a}$ \\
\hline$<5$ years & 47 (36.2) & $12.96( \pm 2.91)$ & & $8.81( \pm 2.16)$ & \\
\hline 5-9 years & 33 (25.4) & $13.03( \pm 2.52)$ & & $8.36( \pm 1.71)$ & \\
\hline $10-14$ years & $30(23.1)$ & $13.40( \pm 2.76)$ & & $8.58( \pm 1.76)$ & \\
\hline$\geq 15$ years & $20(15.4)$ & $14.20( \pm 2.39)$ & & $7.99( \pm 1.77)$ & \\
\hline Medication & & & $0.14^{a}$ & & $0.32^{a}$ \\
\hline $\begin{array}{l}\text { Oral } \\
\text { hypoglycemic } \\
\text { agent }(\mathrm{OHA}) \\
\text { only }\end{array}$ & $59(45.4)$ & $12.98( \pm 2.44)$ & & $8.81( \pm 2.07)$ & \\
\hline Insulin only & $14(10.8)$ & $12.43( \pm 2.06)$ & & $8.08( \pm 1.82)$ & \\
\hline $\mathrm{OHA}+$ insulin & 57 (43.8) & $13.77( \pm 3.03)$ & & $8.39( \pm 1.74)$ & \\
\hline
\end{tabular}

Data are $M \pm S D$.

*Significant $(P<0.05)$.

Tests were ${ }^{a}$ One-way analysis of variance and ${ }^{b}$ independent sample $t$-test.

Coefficients that represent type 2 diabetes patients $(n=130)$ are DKQ, Diabetes

Knowledge Questionnaire; HbA1c, glycated hemoglobin.

\section{Patients' Diabetes Knowledge}

The median scores plus inter-quartile ranges (IQR) of DKQ and HbA1c with respect to patients' demographics are presented in Table 1. Significant difference in DKQ scores was observed between educational levels of the patients. The DKQ with mean score $14.32( \pm 2.14)$ was observed with patients having university level education $(P<0.05)$, whereas no significant difference was observed in different age groups, gender, duration of diabetes, and insulin use $(P>0.05)$.

\section{Known Groups' Validity}

The mean $\mathrm{HbA1c}$ of the patients was $8.55 \%( \pm 1.91)$. The results of one-way analysis of variance (ANOVA) revealed a statistically significant difference $(P<0.05)$ between DKQ scores of patients with "good glycemic control" (HbAlc $\leq 7.5 \%)$, "medium glycemic control" (HbAlc 7.6-8.9\%), and "poor glycemic control" $(\mathrm{HbA} 1 \mathrm{c} \geq 9.0 \%)[F(2,127)=5.336, P=0.006]$. Post hoc comparisons using Scheffe test indicated that the mean DKQ score of patients with "good glycemic control" ( $\mathrm{M}=14.22$, SD 2.4) was statistically different from the patients with "poor control" $(\mathrm{M}=12.56$, SD 2.74). However, the mean DKQ score of patients with "medium glycemic control" $(12.85 \pm 2.74)$ did not statistically differ from the mean DKQ scores of patients with "good medium glycemic control" and "poor glycemic control," detailed results are shown in Table 3. 


\section{Linear Logistic Regression}

A significant regression equation was observed $[F(7,119)=2.472$, $P<0.05$ ], with an $R^{2}$ of 0.076 . Patients' $\mathrm{HbA1c}(\mathrm{OR}-0.17$, CI -1.111 to 0.023 ) and education (OR $0.17, \mathrm{CI}-0.032$ to 0.758 ) were observed to be the significant predictors for DKQ sum score followed by longer diabetes disease duration (OR 0.13, CI -1.192 to 0.817$)$ and older age $(\mathrm{OR}-0.11, \mathrm{CI}-1.119$ to 0.281$)$. Whereas type of hypoglycemic medication, gender, and BMI categories were found to be least significant predicting variables for DKQ sum scores, details are presented in Table 4.

TABLE 2 | Distribution of scores, test item difficulty (percent correct), discrimination (item-total correlation), internal consistency in case of deletion, and correlations with $\mathrm{HbA} 1 \mathrm{c}$ of the 24-item Diabetes Knowledge Questionnaire at baseline $(N=130)$.

\begin{tabular}{|c|c|c|c|c|c|}
\hline $\begin{array}{l}\text { Item } \\
\text { no. }\end{array}$ & $\begin{array}{l}\text { Distribution of } \\
\text { item scores }\end{array}$ & $\begin{array}{l}\text { Percent } \\
\text { correct }\end{array}$ & $\begin{array}{c}\text { Corrected } \\
\text { item-total item c } \\
\text { correlation }\end{array}$ & $\begin{array}{c}\alpha \text { if } \\
\text { deleted }\end{array}$ & $\begin{array}{l}\text { Correlation } \\
\text { with HbA1c }\end{array}$ \\
\hline 1. & $1.32 \pm 0.54$ & 26 & 0.151 & 0.70 & -0.15 \\
\hline 2. & $1.34 \pm 0.72$ & 75 & 0.398 & 0.68 & 0.03 \\
\hline 3. & $2.02 \pm 0.96$ & 11 & 0.410 & 0.68 & $-0.20^{*}$ \\
\hline 4. & $2.14 \pm 0.81$ & 30 & 0.383 & 0.68 & -0.06 \\
\hline 5. & $1.09 \pm 0.39$ & 95 & 0.289 & 0.69 & -0.13 \\
\hline 6. & $1.34 \pm 0.73$ & 81 & 0.414 & 0.70 & 0.08 \\
\hline 7. & $1.27 \pm 0.57$ & 16 & 0.286 & 0.69 & 0.08 \\
\hline 8. & $1.07 \pm 0.33$ & 95 & 0.203 & 0.70 & -0.08 \\
\hline 9. & $1.88 \pm 0.58$ & 60 & 0.298 & 0.67 & 0.01 \\
\hline 10. & $1.88 \pm 0.44$ & 75 & 0.190 & 0.66 & -0.06 \\
\hline 11. & $1.56 \pm 0.88$ & 63 & 0.477 & 0.70 & 0.05 \\
\hline 12. & $2.03 \pm 0.94$ & 15 & 0.500 & 0.70 & 0.12 \\
\hline 13. & $1.35 \pm 0.51$ & 41 & 0.186 & 0.68 & -0.07 \\
\hline 14. & $1.82 \pm 0.83$ & 45 & 0.345 & 0.70 & $0.24^{\dagger}$ \\
\hline 15. & $1.06 \pm 0.27$ & 95 & 0.121 & 0.70 & $-0.18^{*}$ \\
\hline 16. & $1.05 \pm 0.31$ & 97 & 0.252 & 0.72 & 0.15 \\
\hline 17. & $1.31 \pm 0.54$ & 19 & -0.164 & 0.73 & $0.18^{*}$ \\
\hline 18. & $1.42 \pm 0.67$ & 72 & -0.194 & 0.69 & $0.24^{\dagger}$ \\
\hline 19. & $1.22 \pm 0.61$ & 82 & 0.274 & 0.70 & 0.10 \\
\hline 20. & $1.33 \pm 0.69$ & 80 & 0.321 & 0.69 & $0.22^{*}$ \\
\hline 21. & $1.85 \pm 0.71$ & 47 & 0.229 & 0.70 & -0.14 \\
\hline 22. & $1.92 \pm 0.62$ & 61 & 0.416 & 0.78 & -0.05 \\
\hline 23. & $1.55 \pm 0.67$ & 35 & -0.045 & 0.72 & $0.27^{\dagger}$ \\
\hline 24. & $1.12 \pm 0.35$ & 12 & 0.077 & 0.70 & -0.06 \\
\hline
\end{tabular}

Data are $M \pm S D$, Pearson's correlations, Cronbach's $\alpha$, or Spearman's $\rho$.

Correlations with $\mathrm{HbA} 1 \mathrm{c}$ are Spearman's $\rho$.

${ }^{*} P<0.05$ (two-tailed test).

${ }^{\dagger} P<0.01$ (two-tailed test).

\section{DISCUSSION}

Optimum diabetes self-care is imperative for diabetes patients without adequate diabetes disease knowledge (9). Different questionnaire have been developed to examine and imparting diabetes disease knowledge. Without adequate disease knowledge, it seems quite difficult for diabetic patients to practice adequate self-care activities. Most of the available questionnaires have multiple options or too lengthy, which makes these difficult to administer to the diabetes patients in developing countries with low literacy rate $(9,15,16)$. Moreover, very few are valid and reliable, and none is available in Urdu language. DKQ is a relatively simple study tool with three options (Yes, No, or don't know) to select and covering major domains for disease knowledge assessment, like diet, blood glucose self-monitoring, physical activity, and medication intake behavior. A critical review of the patient's response can be used to educate patients and provide opportunities for further research in this domain. Thus, the main objective of this study was to translate the English version of DKQ in to Urdu language and second evaluate the psychometric properties of the translated Urdu version of the DKQ using a convenience sample of patients with type 2 diabetes in Pakistan. This study was the first to systematically translate and validate the 24 -item DKQ in Urdu language.

Overall, a good internal consistency (Cronbach's $\alpha$ ) was observed for the Urdu version of DKQ in our study among Pakistani type 2 diabetes, which is comparable to its Spanish version (10).

Manystudies report a significant association of glycemic control with patients' diabetes disease knowledge (17-19). In this study, patients' glycemic control was assessed by their recent $\mathrm{HbA1c}$ test, and patients with good glycemic control (HbAlc $\leq 7.5 \%$ ) scored significantly higher $(P<0.05)$ DKQ scores as compared to patients with $\mathrm{HbAlc}$ values greater than $7.5 \%$, this finding is in line with that of Al-Qazaz study (19).

It was revealed by multiple linear regression analysis that patients' education, age, HbAlc level, and diabetes disease duration are important predictors for DKQ sum scores. Better disease knowledge was observed in patients with longer disease duration and older age, whereas gender, body mass index, and type of hypoglycemic agents were insignificantly associated with patients' DKA score. Results of this study indicate that lower education level has an impact on diabetes knowledge, and it

TABLE 3 | Comparison of the DKQ sum scores with patients' HbA1c $\leq 7.5 \%$, from 7.6 to $8.9 \%$, and $\geq 9.0 \%(N=130)$.

\begin{tabular}{|c|c|c|c|c|c|c|}
\hline \multirow[t]{2}{*}{ (I) Hb1Ac categories } & \multirow[t]{2}{*}{ Mean DKQ ( $(\mathrm{SD})$} & \multirow[t]{2}{*}{ (J) Hb1Ac categories } & \multirow[t]{2}{*}{ Mean difference $(I-J)$} & \multirow[t]{2}{*}{ Sig. } & \multicolumn{2}{|c|}{$95 \%$ Confidence interval } \\
\hline & & & & & Lower bound & Upper bound \\
\hline \multirow[t]{2}{*}{$\mathrm{HbA} 1 \mathrm{c} \leq 7.5 \%(n=49)$} & $14.22 \pm 2.4$ & HbA1c 7.6-8.9\% & 1.37 & 0.066 & -0.0708 & 2.8055 \\
\hline & & $\mathrm{HbA} 1 \mathrm{c} \geq 9.0 \%$ & $1.66^{\star}$ & 0.010 & 0.3252 & 2.9933 \\
\hline \multirow[t]{2}{*}{ HbA1c $7.6-8.9 \%(n=35)$} & $12.86 \pm 2.74$ & $\mathrm{HbA} 1 \mathrm{c} \leq 7.5 \%$ & -1.37 & 0.066 & -2.8055 & 0.0708 \\
\hline & & $\mathrm{HbA} 1 \mathrm{c} \geq 9.0 \%$ & 0.29 & 0.884 & -1.1656 & 1.7495 \\
\hline \multirow[t]{2}{*}{$\mathrm{HbA} 1 \mathrm{c} \geq 9.0 \%(n=46)$} & $12.56 \pm 2.75$ & $\mathrm{HbA} 1 \mathrm{c} \leq 7.5 \%$ & $-1.66^{\star}$ & 0.010 & -2.9933 & -0.3252 \\
\hline & & HbA1c $7.6-8.9 \%$ & -0.29 & 0.884 & -1.7495 & 1.1656 \\
\hline
\end{tabular}

Data are $M \pm S D$.

Tests were one-way ANOVA and Scheffe test for post hoc group comparisons. Scheffe test significance is expressed: ${ }^{*} P<0.05$.

$D K Q$, Diabetes Knowledge Questionnaire; HbA1c, glycated hemoglobin; ANOVA, analysis of variance. 
TABLE 4 | Linear logistic regression between DKQ sum score and different variables of study participants $(N=130)$.

\begin{tabular}{lrrr}
\hline & & \multicolumn{2}{c}{$95 \% \mathbf{C l}$} \\
\cline { 3 - 4 } Variable & OR & Lower bound & Upper bound \\
\hline Type of hypoglycemic agent & 0.09 & -0.289 & 0.780 \\
Education categories & 0.17 & -0.032 & 0.758 \\
Hb1Ac categories & -0.17 & -1.111 & 0.023 \\
Gender & -0.06 & -1.309 & 0.647 \\
BMl categories & 0.03 & -0.517 & 0.755 \\
Age categories & -0.11 & -1.119 & 0.281 \\
Diabetes disease duration & 0.13 & -0.192 & 0.817 \\
\hline
\end{tabular}

Coefficients that represent type 2 diabetes patients $(n=130)$ are $D K Q$, Diabetes Knowledge Questionnaire; HbA1c, glycated hemoglobin; BMI, body mass index. Type of hypoglycemic agent (ref OHA only); Education categories (ref No formal Education); HbA1C categories (ref $\leq 7.5 \%$ ); gender (ref female); BMI categories (ref underweight); age categories (ref < 45 years); diabetes disease duration (ref $<5$ years).

is similar to the evidence shown in earlier studies $(20,21)$. So, patients with higher education and longer disease duration were observed to have better diabetes disease knowledge and better glycemic control too.

\section{CONCLUSION}

There is need to assess and improve the patients' diabetes knowledge, which is very important for an effective self-care and achieving optimum glycemic control. The findings of this study support that the Urdu version of the DKQ a valid instrument for measuring patients' diabetes knowledge. This finding is in line with our hypotheses as patients with higher DKQ scores were expected to have better glycemic control. The good associations between glycemic control and scores of the Urdu version of DKQ suggest that helping patients to improve their diabetes disease knowledge might lead to improved self-care and reduced risks of disease-related complications.

\section{REFERENCES}

1. Raaijmakers LG, Martens MK, Bagchus C, de Weerdt I, de Vries NK, Kremers SP. Correlates of perceived self-care activities and diabetes control among Dutch type 1 and type 2 diabetics. J Behav Med (2015) 38(3):450-9. doi:10.1007/s10865-014-9609-y

2. Atlas IDFI. IDF DIABETES ATLAS [Online]. (2016). Available from: http:// www.diabetesatlas.org/

3. Bahadar H, Mostafalou S, Abdollahi M. Growing burden of diabetes in Pakistan and the possible role of arsenic and pesticides. J Diabetes Metab Disord (2014) 13(1):117. doi:10.1186/s40200-014-0117-y

4. Diabetes Control and Complications Trial Research Group, Nathan DM, Genuth S, Lachin J, Cleary P, Crofford O, et al. The effect of intensive treatment of diabetes on the development and progression of long-term complications in insulin-dependent diabetes mellitus. N Engl J Med (1993) 329:977-86.

5. Esteghamati A, Khalilzadeh O, Anvari M, Meysamie A, Abbasi M, Forouzanfar M, et al. The economic costs of diabetes: a population-based study in Tehran, Iran. Diabetologia (2009) 52(8):1520-7. doi:10.1007/s00125009-1398-4

6. Dall TM, Zhang Y, Chen YJ, Quick WW, Yang WG, Fogli J. The economic burden of diabetes. Health Aff (2010) 29(2):297-303. doi:10.1377/ hlthaff.2009.0155

\section{Strength and Limitations}

This study is the first to translate and validate the DKQ in Urdu language. A possible limitation of this study is that it was used to assess diabetes knowledge in type 2 diabetes patients; diabetes type 1 patients should also be recruited to establish validity and reliability of this tool across both major diabetes types. Low literacy rate of the respondents is another limitation of this study, as it might limit generalizability to other patient groups. However, the results of this study could be generalized to the community as the data were collected from the institutional diabetic clinics, which cater the needs of majority of diabetic patients. The strength of this study lies in the standardized data assessment using structured interviews and $\mathrm{HbAlc}$ analysis in one laboratory. Moreover, DKQ is relatively easy to administer to administer.

\section{ETHICS STATEMENT}

This study was approved and carried out with the recommendations of the Monash University Human Research and Ethics Committee (MUHREC), Akuwat diabetic clinic Lahore, and Awan Medical Complex Lahore. Written consent was provided by all subjects before participation in the study, in accordance with the Declaration of Helsinki.

\section{AUTHOR CONTRIBUTIONS}

$\mathrm{AB}$ and TK: conception, design of the work, the acquisition, analysis, interpretation of data for the work, drafting the work, revising it critically, and final approval of the version to be published. PP, SL, and AK: design of the work, interpretation of data for the work, drafting the work, revising it critically, and final approval of the version to be published. AB, TK, PP, AK, and SL agreed to be accountable for the content of the work.

7. Beard E, Clark M, Hurel S, Cooke D. Do people with diabetes understand their clinical marker of long-term glycemic control (HbAlc levels) and does this predict diabetes self-care behaviours and HbAlc? Patient Educ Couns (2010) 80(2):227-32. doi:10.1016/j.pec.2009.11.008

8. Beeney LJ, Dunn SM. Knowledge improvement and metabolic control in diabetes education: approaching the limits? Patient Educ Couns (1990) 16(3):217-29. doi:10.1016/0738-3991(90)90071-R

9. Fitzgerald JT, Funnell MM, Hess GE, Barr PA, Anderson RM, Hiss RG, et al. The reliability and validity of a brief diabetes knowledge test. Diabetes Care (1998) 21(5):706-10. doi:10.2337/diacare.21.5.706

10. Garcia AA, Villagomez ET, Brown SA, Kouzekanani K, Hanis CL. The Starr county diabetes education study development of the Spanish-Language Diabetes Knowledge Questionnaire. Diabetes Care (2001) 24(1):16-21. doi:10.2337/diacare.24.1.16

11. Norris SL, Engelgau MM, Narayan KV. Effectiveness of self-management training in type 2 diabetes a systematic review of randomized controlled trials. Diabetes Care (2001) 24(3):561-87. doi:10.2337/diacare.24.3.561

12. American Diabetes Association. 4. Foundations of care: education, nutrition, physical activity, smoking cessation, psychosocial care, and immunization. Diabetes Care (2015) 38(Suppl 1):S20-30. doi:10.2337/dc15-S007

13. Bradley C. Translation of questionnaires for use in different languages and cultures. Handbook of Psychology and Diabetes: A Guide to Psychological Measurement in Diabetes Research and Practice. (1994). p. 43-55. Available 
from: http://www.healthpsychologyresearch.com/publications-and-posters/ publications/handbook-psychology-and-diabetes-guide-psychological

14. George D, Mallery P. SPSS for Windows Step by Step: A Simple Guide and Reference, 11.0 Atualização (4a edição). Boston: Allyn \& Bacon (2003).

15. Ahmad B, Ramadas A, Quek K. The development and validation of Diabetes Knowledge Questionnaire for the indigenous population in Malaysia. Med J Malaysia (2010) 65(4):273-6.

16. Eigenmann C, Skinner T, Colagiuri R. Development and validation of a Diabetes Knowledge Questionnaire. Pract Diabetes Int (2011) 28(4):166-70d. doi:10.1002/pdi.1586

17. Bloomgarden ZT, Karmally W, Metzger MJ, Brothers M, Nechemias C, Bookman J, et al. Randomized, controlled trial of diabetic patient education: improved knowledge without improved metabolic status. Diabetes Care (1987) 10(3):263-72. doi:10.2337/diacare.10.3.263

18. Sánchez CD, Newby LK, McGuire DK, Hasselblad V, Feinglos MN, Ohman EM. Diabetes-related knowledge, atherosclerotic risk factor control, and outcomes in acute coronary syndromes. Am J Cardiol (2005) 95(11):1290-4. doi:10.1016/j.amjcard.2005.01.070

19. Al-Qazaz HK, Hassali MA, Shafie AA, Sulaiman SAS, Sundram S. The 14-item Michigan diabetes knowledge test: translation and validation study of the
Malaysian version. Pract Diabetes Int (2010) 27(6):238-41a. doi:10.1002/ pdi.1495

20. Heisler M, Piette JD, Spencer M, Kieffer E, Vijan S. The relationship between knowledge of recent $\mathrm{HbAlc}$ values and diabetes care understanding and self-management. Diabetes Care (2005) 28(4):816-22. doi:10.2337/ diacare.28.4.816

21. Rafique G, Azam S, White F. Diabetes knowledge, beliefs and practices among people with diabetes attending a university hospital in Karachi, Pakistan. East Mediterr Health J (2006) 12(5):590-8.

Conflict of Interest Statement: The authors declare that the research was conducted in the absence of any commercial or financial relationships that could be construed as a potential conflict of interest.

Copyright (C) 2017 Bukhsh, Lee, Pusparajah, Khan and Khan. This is an open-access article distributed under the terms of the Creative Commons Attribution License (CC $B Y)$. The use, distribution or reproduction in other forums is permitted, provided the original author(s) or licensor are credited and that the original publication in this journal is cited, in accordance with accepted academic practice. No use, distribution or reproduction is permitted which does not comply with these terms. 


\section{APPENDIX}

TABLE A1 | Diabetes Knowledge Questionnaire (Urdu Version).

\begin{tabular}{|c|c|c|c|c|}
\hline 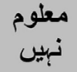 & نهيب & بان & 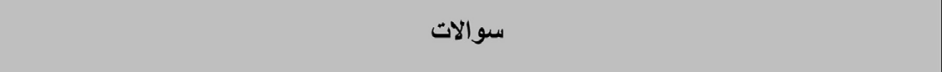 & نمبر \\
\hline & & & ذيابيطس كا سبب بهت زياده ميثها كهانا اور كهانـ كى ديكر ميثهى اشبياء بين. & 1 \\
\hline & & & | ذيابيطس جسم ميب مؤثر انسولين كى كمى كى وجم سـ بوتى بـ - & 2 \\
\hline & & & 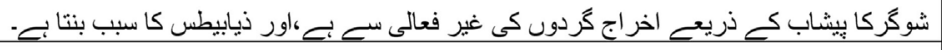 & 3 \\
\hline & & & 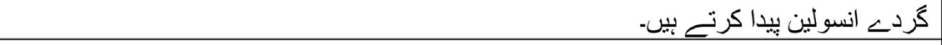 & 4 \\
\hline & & & 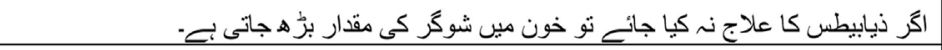 & 5 \\
\hline & & & اكر مجهح ذيابيطس به تو مير ـ بجون كو ذيابيطس بونه كا امكان زياده بــ. & 6 \\
\hline & & & ذيابيطس نهيك نبيس بو سكتى. & 7 \\
\hline & & & خالى بيث خون ميل شوكركى سطح 210 بت زياده بـ - & 8 \\
\hline & & & |ذيابيطس كو قيى كرنح كا بيترين طريق يبشاب كى جانج بـ . & 9 \\
\hline & & & 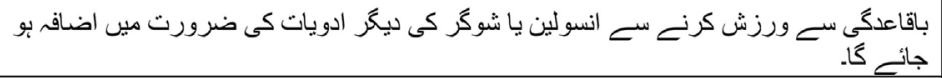 & 10 \\
\hline & & & 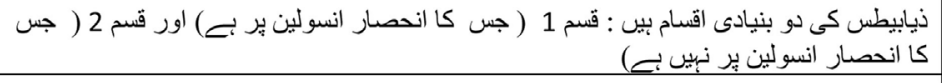 & 11 \\
\hline & & & 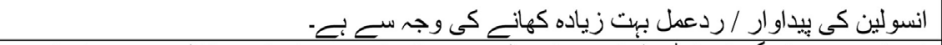 & 12 \\
\hline & & & 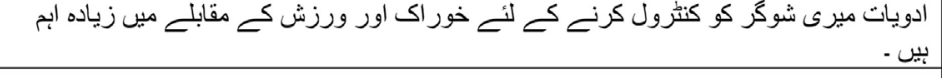 & 13 \\
\hline & & & لـيابيطس اكثر خون كى كردش مبي كمى كا سبب بنتى بـ - & 14 \\
\hline & & & ذيابيطس ميب جلدى خُر اش اور زخم آبستر آبستر مندمل بوتــ بيل. & 15 \\
\hline & & & 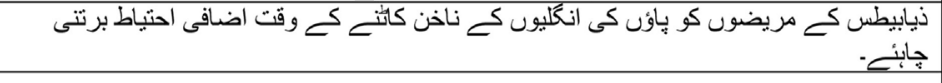 & 16 \\
\hline & & & ذيابيطس كـ مريضكو زخم آيوذين اور الخحل كــ ساته صاف كرنا جائهــ. & 17 \\
\hline & & & 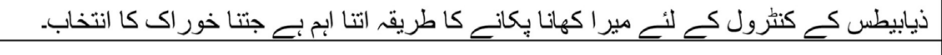 & 18 \\
\hline & & & ذيابيطس مير كردون كو نقصان يهنجا سكتى بـ. & 19 \\
\hline & & & ذيابيطس مبر بح باتهوب اور ياؤن كى انكليون ميل احساس كى كمى يبدا كر سكتى بــ- & 20 \\
\hline & & & 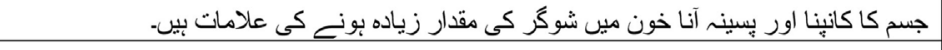 & 21 \\
\hline & & & 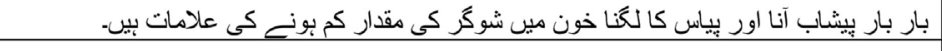 & 22 \\
\hline & & & 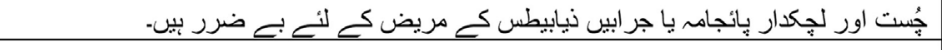 & 23 \\
\hline & & & 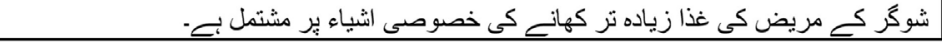 & 24 \\
\hline
\end{tabular}

Translated and Adapted by Allah Bukhsh and Tahir Mehmood Khan (allah.bukhsh@monash.edu, tahir.mehmood@monash.edu) School of Pharmacy, MONASH University, Malaysia, 2016.

This product was adapted from the DKQ "Diabetes Knowledge Questionnaire" - Garcia and Associates for the diabetes selfmanagement project at Gateway Community Health Center, Inc. with support from the Robert Wood Johnson Foundation ${ }^{\otimes}$ in Princeton, NJ, USA. 